\title{
Joint singing as a means of cultural transmission in Estonia
}

\author{
Raudsepp, Inge
}

2015

Raudsepp , I , Sepp , A \& Ruokonen , I 2015 , ' Joint singing as a means of cultural transmission in Estonia ', Society. Integration. Education : Proceedings of the International Scientific Conference , vol. Vol 2 (2015) , pp. 155-164 . https://doi.org/10.17770/sie2015vol2.455

http://hdl.handle.net/10138/311601

https://doi.org/10.17770/sie2015vol2.455

unspecified

publishedVersion

Downloaded from Helda, University of Helsinki institutional repository.

This is an electronic reprint of the original article.

This reprint may differ from the original in pagination and typographic detail.

Please cite the original version. 


\title{
JOINT SINGING AS A MEANS OF CULTURAL TRANSMISSION IN ESTONIA
}

\author{
Inge Raudsepp \\ Foundatsion Innove \\ Anu Sepp \\ Estonian Academy of Music and Science \\ Inkeri Roukonen \\ University of Helsinki
}

\begin{abstract}
The phenomenon of joint singing, originating from the traditional old folk song and subsequent choral singing, has developed in Estonia into a significant cultural metaphorSong Celebrations. Recent decades have brought about rapid changes in Estonian sociocultural reality: the process of globalisation has raised the question of how to maintain national identity and cultural traditions considering these rapid processes.

The aim of this article is to analyse phenomena of joint singing and Song Celebrations through historical, cultural and educational lens. The subject and corresponding literature were analysed using hermeneutic approach by M. Heidegger, W. Dilthey and H.-G. Gadamer, reflected through the focus of culture and cultural transmission by L.Rauhala, R.McShea, M.J. Taylor and C. A. Thoth. The drifts of the content and developmental tendencies of joint singing and Song Celebrations between 1962-2011 were investigated by means of comparative analysis.

The phenomenon of joint singing that has developed into the Song Celebrations tradition continues to be one the main means of cultural transmission in Estonia.
\end{abstract}

Keywords: cultural transmission, joint singing, music education, Song Celebration.

\section{Introduction}

The phenomenon of culture has been defined and referred to as one of the most complicated terms to be explained by numerous authors (Tylor, 1920; Geertz, 1973; McShea, 1990; Rauhala, 2006; Taylor \& Thoth, 2011). Culture is described as a collection of beliefs, attitudes, values and behavioural patterns that are generally approved by a group of individuals. It can contain everything from language, marriage practices, and governmental configurations, to descriptions of family, greeting behaviours, home structures, and death rituals, just to name a few (Taylor \& Thoth, 2011). They all agree upon the idea of culture being tightly connected with social practices and being a result of human interaction. "Thus, particular socio-cultural settings are especially important in becoming who we are; we identify ourselves as members of a certain culture in definite social surroundings, including the traits of a social group, ethnicity, race, nationality and region" (Sepp, Ruokonen, Ruismäki, 2012, 113-114). In the given context understanding and interpretation of connections between the past and the present, as well as finding implications based on the hermeneutic 
approach, are of more importance. Existing connection between individual and society helps to find the background of one's motivation and relations with the past, realizing its reflection of the present time (Dilthey, Gadamer, Heidegger, 1997).

According to M. J. Taylor and C. A. Thoth cultural transmission "is the process through which cultural elements, in the form of attitudes, values, beliefs, and behavioural scripts, are passed onto and taught to individuals and groups" (Taylor \& Thoth, 201, 448). They identify two processes through which culture is acquired and taught: enculturation and socialization.

Enculturation signifies the process through which an individual learns aspects of a surrounding, existing culture. This process can be seen as nondeliberate, informal, and indirect, meaning that an individual learns cultural elements by being exposed to them, usually living and being part of the culture.

The process of socialization represents a means through which an individual learns about culture, but with an important difference: the individual is specifically, particularly and purposefully led to acquire culturally recognized attitudes, values, beliefs, and behaviours. Socialization can be seen more as a process of teaching an individual about a certain culture.

Enculturation and socialization are not always mutually exclusive activities and can occur concurrently and may be lifelong processes taking place in different contexts. The goals of both processes are to prepare individuals to become successfully acting members of society; teach culturally desirable behaviours of a certain culture and pass the essential traditions to the next generations (Taylor \& Thoth, 2011).

In the context of music education and singing, the component of enculturation in passing on singing traditions through folk songs and musicing at home has lost its leading role. Instead, the role of joint singing has gained a significant role as a means of socialization in Estonian culture, cultivating also social competence and empathy as well as self-identity (Ammon, 1974; Tormis 2000; Vikat 1998).

\section{The historical and cultural and background of joint singing in Estonia}

Joint singing represents an important phenomenon in the Estonian musical culture. The origins of joint singing rest in older folk songs (runic songs) and church hymns that laid the basis to widely spread choir singing traditions.

Runic songs represent a typical style of singing among different ethnic groups living around the Gulf of Finland, belonging also to Estonian musical heritage. The form of these songs emerged about two millennia ago their initial function being the intra-community interaction through traditional rites and customs. Runic songs are based on recitative unison singing of a narrow-range archaic tune, which is performed in turn by a lead singer and a choir, the latter repeating the verse sung by the lead singer. This kind of singing can be viewed as an interactional act of solidarity (Kuutma, 2006). 
Runic songs accompanied Estonians throughout their lives and were an organic part of their daily lives expressing the thoughts and feelings of the singers. These songs were believed to hold a certain "power" - that is why the songs often reveal reality figuratively using metaphoric symbols and being part of oral folk traditions that were passed from generation to generation (Raudsepp \& Vikat, 2009; Sepp, Ruokonen, Ruismäki, 2012).

During the $13^{\text {th }}$ century, with the expansion of Christianity, another type of community singing emerged - the joint singing of a congregation during Roman Catholic liturgical church service, which in the $17^{\text {th }}$ century was replaced by the hymns of Lutheran church. In order to improve the level of choral singing, many churches established schools where students were taught music for better singing of hymns. Together with the spreading of the United Brethren's movement in the $18^{\text {th }}$ century, new sacred songs started to replace traditional runic singing. Choir singing in voices following the German culture was taught both in village schools and in the Lutheran church. This movement was supported with the music books used in parish schools: by the end of the $17^{\text {th }}$ century at least five books of choral music containing Lutheran hymns had been published in Estonian, the first ones were published in 1864 by A. Erlemann and in 1868 by F. Kuhlbars. Singing was also a part of curriculum in village and parish schools. For example, in the parish school at Laiuse in 1822, singing lessons were held every day (Andresen, 2003; Raudsepp \& Vikat, 2009; Sepp, Ruokonen, Ruismäki, 2012).

Thus, by the middle of the $19^{\text {th }}$ century a form of joint singing pursuing artistic goals - choir singing - developed powerfully, and by the end of the century it was wide-spread both in towns and in the countryside, following the example of German choral singing. Already in the 1840s song festivities and singing days were organized in different counties of Estonia. As a result of the National Awakening movement in the $19^{\text {th }}$ century, the practice of choir singing grew rapidly in Estonia. The cultural societies named „Estonia“ and „Vanemuine" started to organize music and cultural activities where Estonian national identity was expressed and encouraged.

\section{Song festival as a cultural metaphor}

All these activities led to the First All-Estonian Song Festival which was organised by Vanemuise Society and its leader Voldemar Jannsen (1819-1890). in Tartu, June $18-20,1869$ and dedicated to the $50^{\text {th }}$ anniversary of the Livonian farmers' liberation from serfdom. It turned out to be a truly historic event - a milestone in the development of Estonian national and cultural selfdetermination. The singers of male choirs were invited to participate, for it was believed that men and women from all over Estonia could not have spent even one day together without trouble. In addition to considering such moral aspects, German festivals of male choirs were taken as an example, as well as a wish to exclude the mixed choirs of the orthodox churches. Participants of 46 male 
choirs (822 singers) and 5 brass bands (56 members) took part in this historical event (Leichter, 1991). The repertoire consisted of 15 secular and 12 sacred songs in, most of them written by German composers with Estonian texts, and these were sung in Estonian. There were two original Estonian songs included: Mu isamaa on minu arm (My Homeland is My Love) and Sind surmani (Till I Die) by Aleksander Kunileid, to the poems by Lydia Koidula. Both songs were accepted with great enthusiasm and fascination. There were also two songs from Finland, one being Mu isamaa, mu õnn ja rõõm (My Fatherland, My Happiness and Joy) by Frederic Pacius (the same song is the official anthem of Estonia as well as of Finland at present - only with different words) to which Jannsen had made simple and touching lyrics (Eesti Muusikalugu, 2007).

During the period of the following almost 30 years (1879-1910), six Song Celebrations were organised, all playing a significant part in increasing the cultural and national awareness of Estonians.

The tradition of organizing song festivals every five years started with the proclamation of the Republic of Estonia in 1918 (the Dance and Gymnastic Festival of the First Estonian Games, started in 1934, the predecessors of the later National Dance Festivals that accompany the Song Festivals) (Sepp, Ruokonen, Ruismäki, 2012).

During World War II the tradition of Song Celebrations stopped but was re-established again in 1947. During the years of Soviet occupation (19441991), 10 Song Celebration were organized. Under the Soviet regime cultural activities were allowed and vocal music carrying political messages became favoured as an ideal means of influencing crowds, but endangering Estonian national identity (Lippus, 1997). In that context, joint singing obtained the meaning of a symbol - it was a means of national survival and movement towards independence since people used their cultural heritage and singing as a tool to preserve and support their national identity. These years celebrated the birth of numerous choral songs with enduring value, carrying coded messages of national identity understood by the community belonging to the group. The Finnish ethnomusicologist Suutari (2002), whose research focuses on issues of identity, emphasizes the important role of music in the development of a group's awareness of unity, where music can be comprehended as a symbol and driving force behind a group as well as a shared aesthetic experience joining it and shaping its cultural identity.

One of those really meaningful songs is Mu isamaa on minu arm (My fatherland is my love) by Gustav Ernesaks - which in its multi-layered context embeds the perception of national identity and is a unique symbiosis of coded text and melody - was an unofficial anthem of Estonia during the Soviet occupation period.

As stated by Adorno (1977) the importance and power of arts in confronting repression and injustice is remarkable. The use of music in such occasions may give rise to critical thinking and initiate movements towards 
justice and freedom. The role of music in repressed environments, according to American researchers Flam (1992) and McCarthy (1990), is to support the survival and development of national identity, especially during periods where one ethnic group suffers from political or military oppression by another ethnic group.

The end of 1980s, also known as perestroika, denoted the rise of democratic movement and the national re-awakening in the Estonian society, which emerged as the Singing Revolution during 1988-89. The Singing Revolution is rare and unique: it can be viewed as a noteworthy example of the possibility of a peaceful and efficient resistance. The spontaneous "night song festivals" and political meetings-turned-into- joint singing prepared the ground for the process of regaining independence, demonstrating the organizational power of the phenomenon of joint singing in the expression of national selfconsciousness (Pierson, 1998). In these years a new generation of composers emerged (A. Mattiisen, R. Eespere, R. Rannap, M. Siimer, et al.), whose songs carried the message of patriotism, strengthening and increasing the feeling of national unity. A special place in the process of maintaining national identity and developing joint singing belongs to the composer Alo Mattiisen, who in a professional manner managed to combine the nature of runic songs and rock music. As the result of that process, Estonia regained independence in 1991.

According to Grossberg (1992), such events carry the characteristics of affect, the central force of which being the formation of identity. Affect, however, is not only an emotion arisen from experience, but an ability to produce meanings in music to express one's passion and identity.

\section{Joint singing in the context of music education}

Globalisation processes in the contemporary world and society, but especially media have shaped the pupils in our schools. Keeping that in mind, it needs special attention and approach to maintain and develop national identity through general music education. One of the possibilities is to use the experience of joint singing, which strengthens national identity through the feelings of unity, self-expression, self-realization and self-discovery (Stolovitš, 1992; Adorno 1997).

Those aspects have been included in the syllabi of music of the National Curricula for Basic and Upper Secondary Schools of 2011, where joint singing has a traditionally strong position. The subject syllabi outline the repertoire for joint singing (runic songs, patriotic songs, popular choral songs, etc.) with the aim to enable every child to participate in singing as well as through that support the sustainability of joint singing and social cohesion (National Curricula, 2011).

David J. Elliott (1995) emphasizes the connections between musical practice and culture, stressing that music education does not function separately in a culture, but works powerfully as a culture. He points out a mutual connection between musical culture and the surrounding cultural context which 
are linked by the underlying network of beliefs and values. According to D. Elliott, "the education of musicianship and the achievement of self-growth, constructive knowledge, and musical enjoyment will not occur, if music teachers and learners approach music narrowly (or aesthetically), as a collection of autonomous pieces. To develop full musical understanding and appreciation, we need to re-mind ourselves and others that MUSIC is a diverse artistic-socialcultural practice" (ibid, 198). As stated by D. Elliott, children's choral singing is closely connected to real-world practices of amateur and professional choral singing of different kinds.

Discussing music as culture, D. Elliott points out that "culture, therefore, is not something that people have it is something that people do" (Elliott, 1990, 149). He signifies the importance of giving students opportunities to participate in or "live" a culture (Elliott, 1990) in order to understand its real meaning and purpose. These ideas can be easily transferred to the context of Estonian music education in which focus is given to students' participation in Song Celebrations. All the choirs have gone through a long rehearsing/learning process of the repertoire (praxis) and all the people, including students, have developed their musicianship and are involved in "being situated" in the Song Celebration Grounds by taking part in huge cultural and emotional event. A musical practice is not something that operates autonomously in a culture: it constitutes and is constituted by culture and ideology. Similarly, music education is not something that operates autonomously in a culture; it also functions powerfully as culture (ibid, 212). Each music culture is linked in a two-way relationship to its surrounding cultural context in which the beliefs, allies, and so on that constitute a music culture are constantly being practiced, refined, and modified in relation to larger cultural concerns. Viewed from this perspective, the musical works that grow from musical practices are inseparable: from their roots to their underlying network of beliefs and values.

Singing has been among the most important musical activities in Estonian general music education. The whole concept of Estonian music education had been elaborated by the end of the 1930s by Riho Päts (1899-1977) - an outstanding Estonian composer, music educator, choir conductor and music journalist. In his concept of music education, elementary music theory was wellbalanced and organized through musical activities: singing, movement, and playing instruments. Music education started in kindergarten and continued through the end of upper secondary school (gymnasium), providing the high level music education (Raudsepp, 2013, 100).

In order to promote national identity and unity in the new generation, R. Päts also started to develop a unitary tradition of joint singing as a process, where the ordinary song repertoire learned in music lessons shaped the habit of singing together and was applicable in gatherings, music festivals and other joint events. He developed a new model of music teaching which combined traditional methods (singing together, choir singing) and innovative ideas from 
Europe (e.g. Z. Kodály-method and C. Orff approach) (Päts, 1989). Päts realized the great potential of school choirs in the development of joint singing. He pointed out the important connection between participating in choirs, general music education and extra-curricular music activities, emphasizing the significance of the chosen repertoire (Päts, 1939; 1947). He stressed that the strength of the tradition of joint singing primarily depends on the depth of its roots that reach children and adolescents (Päts, 1940). The functioning of his whole system was warranted by the solid place of music (i.e. singing) in the national curricula of different periods with the number of lessons specified for each class (Sepp, 2009).

By the 1960s, the number of children singing in choirs and the popularity of Song Celebrations had increased to such a level that the idea of organizing special Song Celebrations for children and youth was started in 1962. The role of school choirs in carrying on the idea of national identity and Song Celebrations is of great importance. Thus, it is also the greatest event for joint singing today for the new generation.

Next we will view the dynamics of pupils' participation in Youth Song Celebrations between 1962-2011 (Figure 1) (Ammas, Valner et al., 2011).

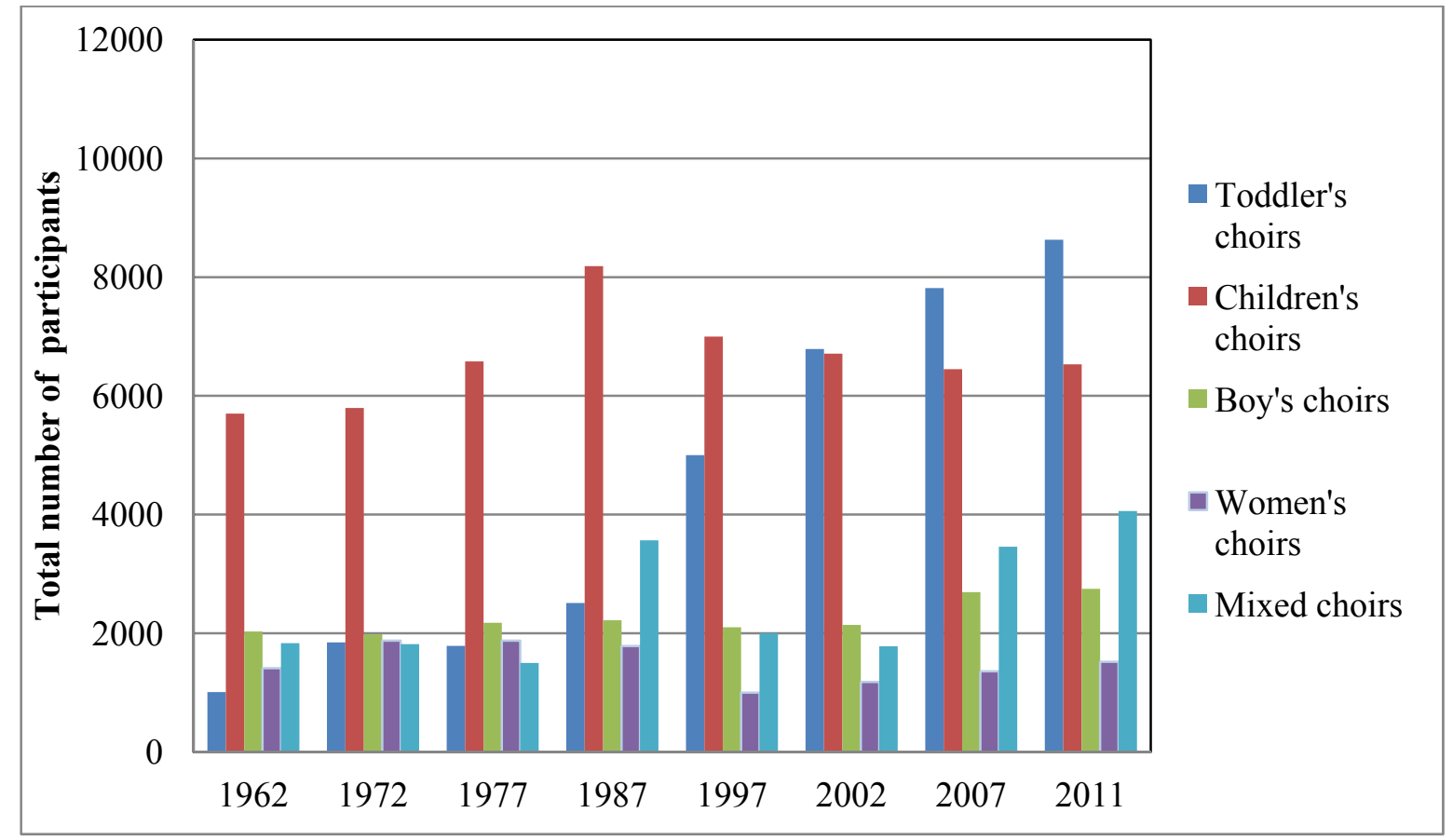

Figure 1. Participants of different choir types in Youth Song Celebrations $(n=)$

The dynamics of different choir types in Figure 1 (toddlers', boys', children's, mixed and women's choirs), reveal that the greatest increase in the number of participants has taken place in toddlers' choirs: from 1,000 pupils in 1962 to over 8,000 in 2011. Involving as many pupils as possible in this choir category has been purposeful: it is the age group where the perception and habit 
of joint singing is formed, thus creating the foundations for practicing choir singing also in the future.

The number of participants in children's choirs increased annually in the period of 1962-1987, decreasing a little during 1987-2007. This trend can be explained by the fact that the number of children's choirs in Russian speaking schools diminished after Estonia regained independence. One possible reason for that could be language problems, but also an increasing level of difficulty of the repertoire. Participation of youth in mixed choirs has made marvellous progress in the recent decade - an increase by almost 2.3 times: in 2002 there were 1,780 and in $2011-4,060$ singers. The shift in the numbers of boys' and female choirs in recent decades has been by 1.3 times. It may be assumed that an increase in the numbers of mixed, female and boys' choirs has been due to the choice of varied and youthful song repertoire, where runic songs as a form of joint singing have become very popular.

Figure 2 shows the dynamics of participation in Youth Song Celebrations in relation to the total number of pupils studying in comprehensive schools (\%).

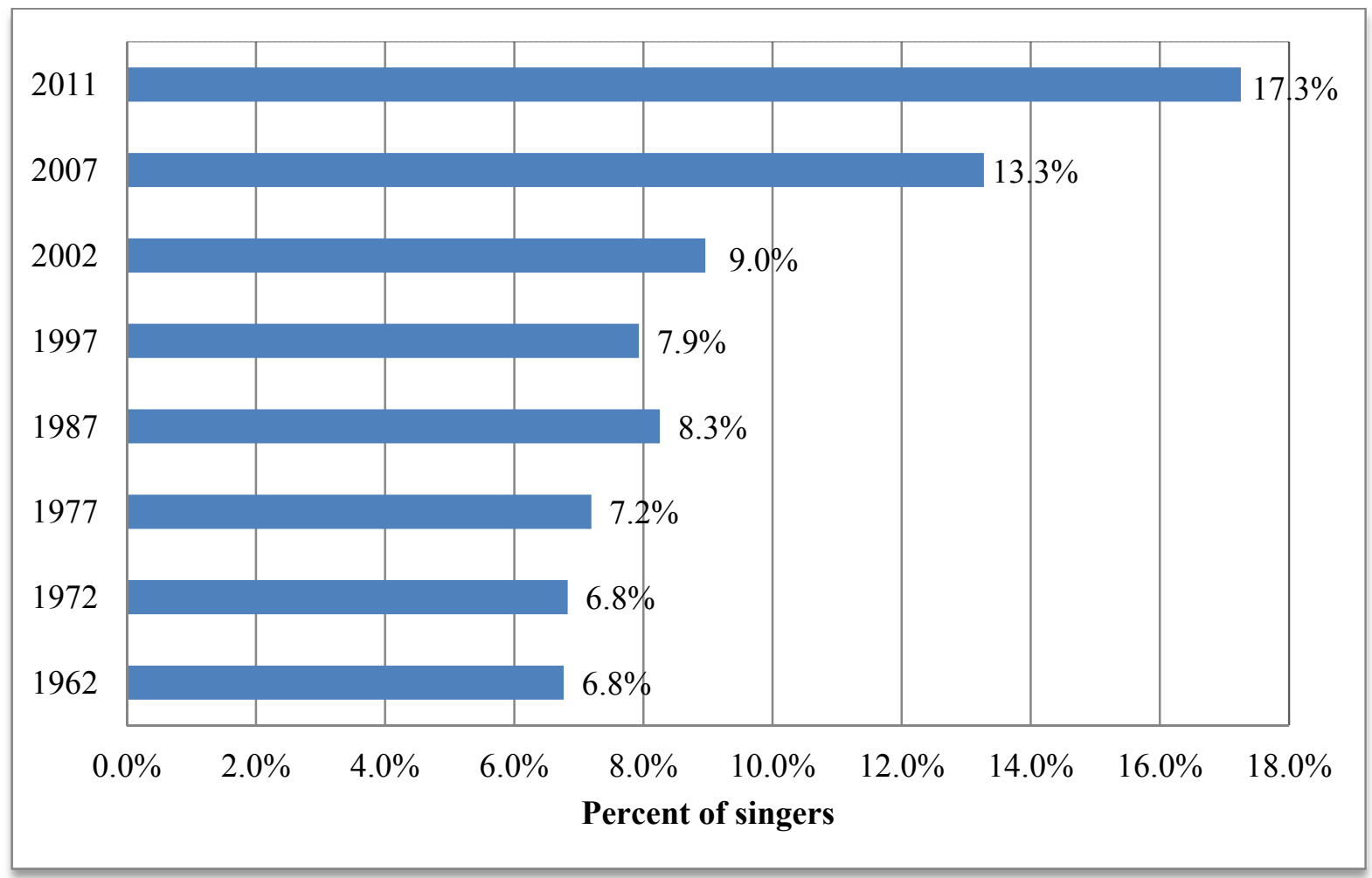

Figure 2. Participants in Youth Song Celebrations in relation to the total number of pupils (\%)

Figure 2 shows that the participation of pupils in the process of Youth Song Celebrations during the period of 1962-2002 has been relatively stable, forming $7 \%$ to $9 \%$ of the total number of pupils in Estonia. A great shift occurred in 2007 (13.3\% from the total number of pupils, an increase by 4\%) and the number of pupils has increased even more in 2011 (17.2\%, an increase by 4\%). 
(Estonian Ministry..., 2011). In the academic year 2014/2015, 21\% of basic and upper secondary school students are involved in the next Youth Song Celebrations preparation process. This can be explained by the popularity of joint singing in the society as a whole. Beside the songs of modern authors also pop and rock music have made their way into the repertoire, often relying on the oldest type of joint singing as a source - runic songs.

\section{Conclusion}

Joint singing has had a special function in the Estonian society for centuries in developing national identity and social cohesion. It has functioned as a means for uniting different social groups in Estonia, increasing multicultural interaction, sustainability and self-determination.

In Estonian schools today the continuity of joint singing is ensured by educational and cultural policies of Estonia. Music education enjoys a respectable position of a mandatory subject in the National Curricula for general comprehensive schools in which joint singing functions through common song repertoire, choir singing practice and Song Celebrations.

The phenomenon of joint singing that has developed into the Song Celebrations tradition continues to be one of the main means of cultural transmission in Estonia.

\section{References}

Aalto, P. (2000). Constructing Post-Soviet Geopolitics in Estonia. A Study in Security, Identity. Acta politica, 19. Helsinki: University of Helsinki.

Adorno, T.W. (1997). Aesthetic Theory. London: The Athlone Press.

Ammas, A., Valner, K., Arraste, A., Moss, I. Noorte laulu- ja tantsupeod [Estonian Youth Song and Dance Celebrations]. (2011). Eesti Kooriühing.

Andresen, L. (2003). Eesti kooli ajalugu [The History of Estonian School]. Tallinn: Avita.

Dilthey, W., Gadamer, H. G., Heidegger, M. (1997). Filosoofilise hermeneutika klassikat [Some classics of philosophical hermeneutics]. Ilmamaa.

Eesti Muusikalugu (2007). [Estonian Music Story]. Tallinn: Talmar ja Põhi.

Estonian Ministry of Education and Reasearch. (2011). Statistics. Tallinn.

Estonian Ministry of Education and Reasearch. (2014). Statistics. Tallinn.

Elliott, D.J. (1990). Music as culture: Toward a multicultural concept of arts education. Journal of Aesthetic Education, 24 (1), 147-166.

Elliott, D.J. (1995). Music Matters: A new philosophy of music education. Oxfrod: Oxford University Press.

Flam, G. (1992). Singing for Survival: Songs of the Lodz Ghetto, 1940-45. Urbana: University of Illinois Press.

Geertz, C. (1973). The Interpretation of Cultures. New York: Basic Books.

Grossberg, L. ( 1992). Is There a Fun in the House?: The Affective Sensibility of Fandom. In L.A. Lewis (Ed.) The Adoring Audience: Fan Culture and Popular Media. (pp. 50-65). London \& New York: Routledge.

Kuutma, K. (2006). Laulupeod rahvusliku identiteedi kandjana [Song Festivals in creating the Estonian cultural identity]. Retrieved January 29, 2009 from http://haldjas.folklore.ee//tagused/nr1/internet.htm 


\section{SOCIETY. INTEGRATION. EDUCATION. Volume II}

Lippus, U. (1997). Baltic Music History Writing: Problems and Perspectives. Acta Musicologia, Vol. LXXI, 1, 50-60.

McCarthy, M. F. (1990). Music education and the quest for cultural identity in Ireland 1831 1989. Michigan: University of Michigan.

McShea, R. J. (1990). Morality and Human Nature: a New route to ethical theory. Philadelphia: Temple University Press.

National Curricula. (2011). https://www.hm.ee/en/national-curricula (28.02.2015)

Pierson, S. (1998). Laulsime end vabaks: muusikaline tegevus ja selle areng eesti kristlaste seas [We achieved our freedom by singing: musical activity and its development among Estonian Christians]. Teater. Muusika. Kino, 12, 43-45.

Päts, R. (1939). Põhialuseid ja lähtekohti muusikalise kasvatuse teostamisel [The foundations and basic views in executing music education]. Muusikaleht, 4/5, 84-89; 7/8, 133-139.

Päts, R. (1940). Ühislaulmisest [About joint singing]. Eesti Kool, 3, 185-187.

Päts, R. (1947). Lastekoorid uue ülesande ees [Children's choirs facing a new task]. Nõukogude Õpetaja, 45, 4.

Raudsepp, I. \& Vikat, M. (2009). Joint singing as a phenomenon of Estonian cultural transmission. Problems of Education in the 21st Century, 13, 103-109.

Raudsepp, I. (2013). Riho Pätsi fenomen Eesti muusikapedagoogikas [The Phenomenon of Riho Päts in Estonian Music Pedagogy]. Tallinn University.

Rauhala, L. (2006). Ihminen kultturissa - kulttuuri ihmisessä [Man in Culture - Culture in Man]. Helsingin Yliopistonpaino. Helsinki University Press.

Sepp, A. (2009). Some highlights of music education in Estonian comprehensive schools. H. Ruismäki, I. Ruokonen (Eds.) Arts Contact Points between Cultures: 1st Intercultural Arts Education Conference: Post-Conference Book. Helsinki: University of Helsinki, $35-43$.

Sepp, A., Ruokonen, I. \& Ruismäki, H. (2012). Review of the choir singing tradition in Estonia: praxial music education and socio-cultural aspects. Problems in Music Pedagogy, vol.10-11, 113-124.

Stolovitš, L. (1992). Esteetika, kunst, mäng [Aesthetics, art, play]. Tallinn: Kunst.

Suutari, P. (2002). Teoreetilisi lähtekohti rootsisoomlaste muusikakogemuse ja identifikatsiooni uurimisel [Theoretical basis for the study of the music experience and identification of Swedish Finns]. In T. Ojamaa, \& I. Rüütel (Eds.), Pärimusmuusika muutuvas ühiskonnas I [Ethnic music in the changing society I] (pp.193-201). Eesti Kirjandusmuuseumi etnomusikoloogia osakond.

Taylor M. J., Thoth C. A. (2011), Cultural Transmissionin. In Goldstein,S., Naglieri J. A. (Eds) Encyclopedia of Child Behavior and Development (pp 448-451). NewYork: Springer.

Tylor, Edward. 1920 [1871]. Primitive Culture. New York: J.P. Putnam's Sons,1.

Tormis, V. (2000). Lauldud sõna [The words sung]. Tartu: Tartu Ülikool.

Vikat, M. (1993). Rahvalaul ja lapsed. Rahvamuusika osast väikese lapse isiksuse arengus. Kollokvium. Kokkuvõtted [Folk song and children. - The role of folk music in the development of the personality of a child. Colloquium. Compendium]. Tallinn: TPÜ kirjastus. 